\title{
Zn-Mo/HZSM-5 Catalyst for Gasoil Range Hydrocarbon Production by Catalytic Hydrocracking of Ceiba pentandra Oil
}

\author{
Yustia Wulandari Mirzayanti, Firman Kurniawansyah, Danawati Hari Prajitno, \\ Achmad Roesyadi* \\ Chemical Reaction Engineering Laboratory, Department of Chemical Engineering, \\ Sepuluh Nopember Institute of Technology, Sukolilo, Surabaya, 60111, Indonesia
}

Received: $8^{\text {th }}$ September 2017; Revised: $9^{\text {th }}$ September 2017; Accepted: $17^{\text {th }}$ September 2017; Available online: 22 $2^{\text {nd }}$ January 2018; Published regularly: $2^{\text {nd }}$ April 2018

\begin{abstract}
Biofuel from vegetable oil becomes one of the most suitable and logical alternatives to replace fossil fuel. The research focused on various metal ratio Zinc/Molybdenum/HZSM-5 (Zn-Mo/HZSM-5) catalyst to produce liquid hydrocarbon via catalytic hydrocracking of Ceiba penandra oil. The catalytic hydrocracking process has been applied in this study to crack Ceiba pentandra oil into a gasoil range hydrocarbon using Zn-Mo/HZSM-5 as a catalyst. The effect of various reaction temperature on the catalytic hydrocracking of Ceiba pentandra oil were studied. The Zn-Mo/HZSM-5 catalyst with metal ratio was prepared by incipient wetness impregnation method. This process used slurry pressure batch reactor with a mechanical stirrer. A series of experiments were carried out in the temperature range from $300-400{ }^{\circ} \mathrm{C}$ for $2 \mathrm{~h}$ at pressure between $10-15$ bar. The conversion and selectivity were estimated. The liquid hydrocarbon product were identified to gasoline, kerosene, and gas oil. The results show that the use of Zn-Mo/HZSM-5 can produce gas oil as the most component in the product. Overall, the highest conversion and selectivity of gas oil range hydrocarbon was obtained when the ZnMo/HZSM-5 metal ratio was $\mathrm{Zn}(2.86$ wt.\%)-Mo(5.32 wt.\%)/HZSM-5 and the name is Zn-Mo/HZSM-5_102. The highest conversion was obtained at $63.31 \%$ and n-paraffin (gas oil range) selectivity was obtained at $90.75 \%$ at a temperature of $400^{\circ} \mathrm{C}$. Ceiba pentandra oil can be recommended as the source of inedible vegetable oil to produce gasoil as an environmentally friendly transportation fuel. Copyright ( $) 2018$ BCREC Group. All rights reserved
\end{abstract}

Keywords: Catalytic hydrocracking; Ceiba pentandra oil; Zinc/Molybdenum/HZSM-5 catalyst; Liquid hydrocarbon

How to Cite: Mirzayanti, Y.W., Kurniawansyah, F., Prajitno, D.H., Roesyadi, A. (2018). Zn-Mo/HZSM5 Catalyst for Gasoil Range Hydrocarbon Production by Catalytic Hydrocracking of Ceiba pentandra oil. Bulletin of Chemical Reaction Engineering \& Catalysis, 13 (1): 136-143 (doi:10.9767/bcrec.13.1.1508.136-143)

Permalink/DOI: https://doi.org/10.9767/bcrec.13.1.1508.136-143

\section{Introduction}

Continuous use of fossil fuels creates a negative impact on the environment such as acceler-

*Corresponding Author.

E-mail: aroesyadi@yahoo.com (Achmad Roesyadi) ate global warming, $\mathrm{CO}_{2}$ emissions, greenhouse effects and air pollution and other environmental problems [1-4]. One of the efforts made to overcome the energy crisis is to develop fuel from sources of renewable energy, to develop fuel from new energy sources. One of the most 
promising alternative fuels is biofuels. Biofuels are defined as solid, liquid or gaseous fuels derived from biomass substrates as renewable or flammable feedstock, and may be used as (partial) substitutes for fossil fuels [5]. In Indonesian regulation (KEPRES) $22 / 2017$, on a primary national energy plan concerning national energy development. Biofuel is considered as an alternative and clean fuel to replace petroleum $[6,7]$. There are several studies inedible oil as promising feedstocks for biofuel production. Biofeeds, such as vegetable oil, lignocellulosic biomass, algae, and sewage sludge, can be feedstock to produce biofuel [8]. Inedible vegetable oil as biofeed can be best choice to solve the issue of competition between the use of vegetable oil as the source of food and that of the fuel.

Therefore, some of inedible oil have been investigated and reported [6-11]. One type of vegetable oil that can be utilized to synthesize bio- hydrocarbons is Ceiba pentandra seed oil. Ceiba pentandra plant is a tropical plant, easily obtained and cultivated in Indonesia. The Ceiba pentandra seed contains about 20-28 \% by weight of oil. Ceiba pentandra plants can produce up to $1160 \mathrm{~kg}$ of seed per hectare per year assuming $25 \%$ oil in seeds. The productivity of kapok oil is approximately $70 \%$ of the soybean productivity oil. So far, kapok seeds has become untapped waste maximally. Ceiba pentandra seed oil is not used as food, because it has a chemical nature that is easy to change [11]. Ceiba pentandra oil is extracted from $k a$ pok seed, as shown in Figure 2(b) and (c). Kapok plant is also called the Java kapok plants, kapok Java, or silk kapok trees. Characteristics of Ceiba pentandra tree crops among others have a high up to 70 meters. The Ceiba pentan$d r a$ plant besides producing fiber also has the potential to produce oil. The kapok seeds are

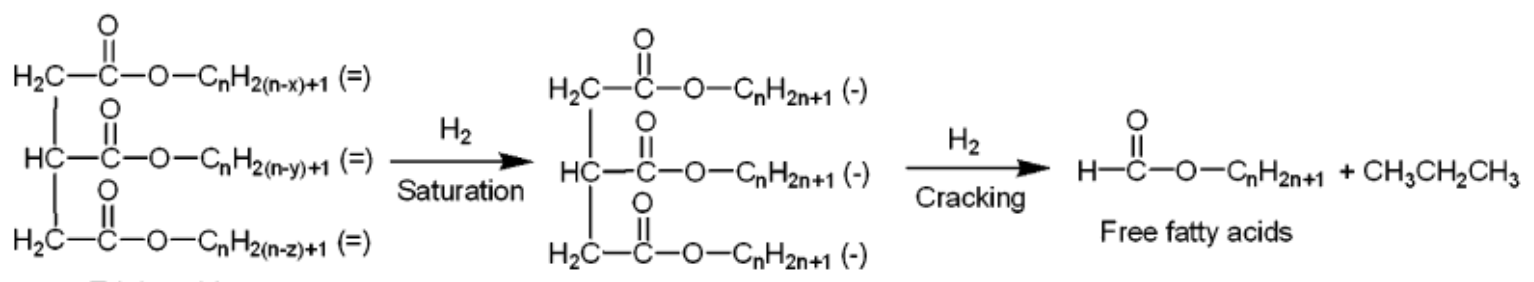

Triglycerides Hydrogenated triglycerides
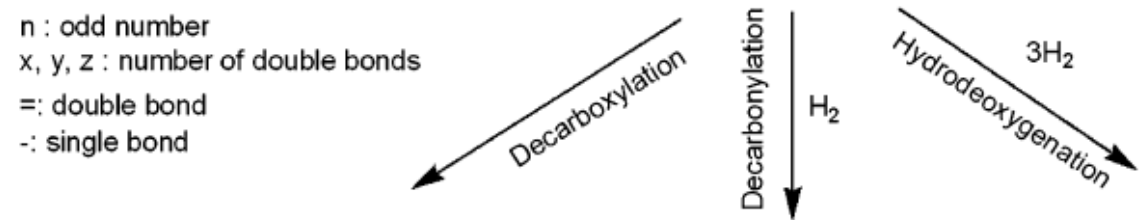

Aromatics

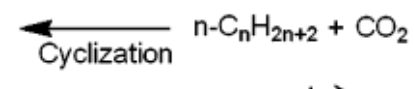

$\mathrm{n}-\mathrm{C}_{\mathrm{n}} \mathrm{H}_{2 \mathrm{n}+2}+\mathrm{CO}+\mathrm{H}_{2} \mathrm{O}$

$n-\mathrm{C}_{\mathrm{n}+1} \mathrm{H}_{2 \mathrm{n}+4}+2 \mathrm{H}_{2} \mathrm{O}$

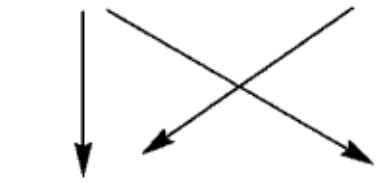

Isomerization

iso- $\mathrm{C}_{n} \mathrm{H}_{2 n+2}$

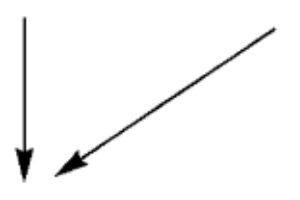

Cracking

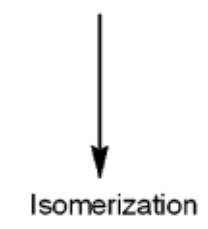

Lighter hydrocrabons

iso- $\mathrm{C}_{n+1} \mathrm{H}_{2 \mathrm{n}+4}$

Figure 1. Triglyceride mechanism using hydrotreating catalyst [14]

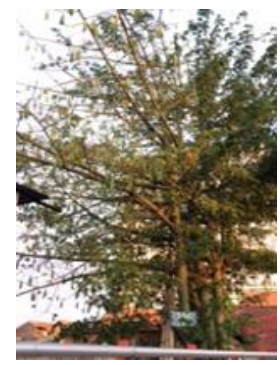

(a)

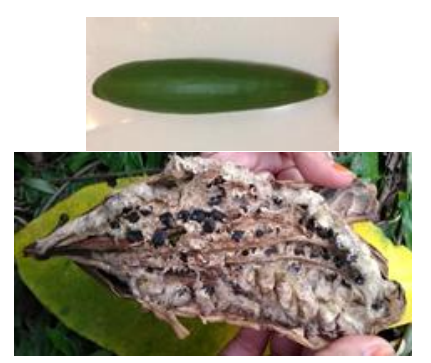

(b)

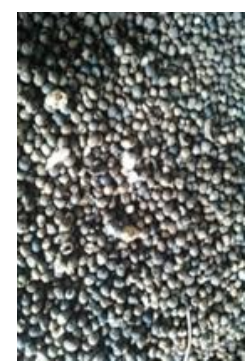

(c)

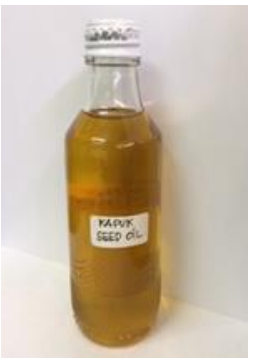

(d)

Figure 2. Ceiba pentandra (a) plant, (b) fruit, (c) seeds, and (d) oil 
blackish, consisting of water content of $13 \%, 5$ $\%$ ash, $20 \%$ crude fiber, $6 \%$ fat, $29 \%$ protein, and $20 \%$ carbohydrates with clean texture and not clot.

The catalytic hydrocracking process is one of the alternative processes for producing biofuels, because it can convert vegetable oils into hydrocarbons in particular $\mathrm{C}_{15}-\mathrm{C}_{18}$ using bifunctional heterogeneous catalysts. Catalytic hydrocracking removes double bonds and carboxyl groups in fatty acids to obtain n-paraffin compounds [12]. The process method of catalytic hydrocracking is the incorporation of catalytic cracking process with the addition of $\mathrm{H}_{2}$ gas. The method is capable of producing biofuels at high temperatures (300-400 ${ }^{\circ} \mathrm{C}$ ) and requires more energy for the process of cracking vegetable oils into hydrocarbons, but producing products that have high oxidation stability and cetane number [10]. The catalytic hydrocracking process involves a hydrodeoxygenation reaction as the main reaction and decarboxylation as a side reaction [13]. Liquid hydrocarbon products generally contain a $\mathrm{n}$-alkane-rich chain of $\mathrm{C}_{15}$ $\mathrm{C}_{18}$ straight through three different reaction stages: decarbonylation, decarboxylation and hydrodeoxygenation [14]. The conversion process of vegetable oils through the catalytic hydrocracking method involves catalysts to speed up the reaction rate and increase selectivity. The conventional catalysts commonly used in the catalytic hydrocracking process are alumina supported by sulphide forms, such as NiMo or CoMo [14-17]. The alumina catalyst $\left(\mathrm{Al}_{2} \mathrm{O}_{3}\right)$ is amorphous and has a texture of a smaller surface area and has a lower acid site when compared with zeolite. Zeolite catalysts have hydrophobic properties that serve to assist the cracking process of vegetable oil triglycerides [18]. The zeolite catalyst HZSM-5 has a strong acid site at high temperatures, capable of forming paraffins and aiding the cracking process [19].

Liquid hydrocarbon biofuel products can be produced from hydroprocessing of carinata oil with $\mathrm{Mo}-\mathrm{Zn} / \mathrm{Al}_{2} \mathrm{O}_{3}$ catalyst [17]. Sousa et al. [20] also reported that biofuel in diesel range can be obtained from hydrotreatment of sunflower oil using supported molybdenum carbide. However, in the study of Zhao et al still use $\mathrm{Al}_{2} \mathrm{O}_{3}$ has smaller surface area and the acid site is lower than zeolite. Therefore, to increase the catalyst activity requires a larger surface area so that HZSM-5 was used to improve the catalyst structure in the previous study [17].

In the present work to focus on various metal ratio Zn-Mo/HZSM-5 catalyst via Ceiba pentandra oil catalytic hydrocracking for liquid hy- drocarbon production. It can be said that the product orientation generated in this research leads to a liquid hydrocarbon product with a composition equal to that of petroleum diesel. The product is called gas oil. The effect of Zinc/ Mo ratio and reaction temperature process on the conversion and the selectivity of gasoil range hydrocarbon were investigated under a relatively low-pressure condition at 10-15 bar.

\section{Materials and Methods}

\subsection{Materials and chemicals}

Ceiba pentandra oil contains unsaturated fatty acids in the form of linoleic acid (C18:2) and palmitic acid (C16:0) were $78.85 \%$ and $21.12 \%$ as a majority composition [21]. Ceiba pentandra oil was analyzed using gas chromatography-mass spectrometry with chromatogram as in the previous study [22].

The ammonium-ZSM-5 zeolite were taken from Zeolyst International (CBV 8014, a surface area of $425 \mathrm{~m}^{2} / \mathrm{g}, \mathrm{Na}_{2} \mathrm{O}$ content less than 0.05 wt.\%), while $\mathrm{Zn}\left(\mathrm{NO}_{3}\right)_{2} .6 \mathrm{H}_{2} \mathrm{O}$ and $\left(\mathrm{NH}_{4}\right)_{6} \mathrm{Mo}_{7} \mathrm{O}_{24 .} 4 \mathrm{H}_{2} \mathrm{O}$ was purchased from Merck with $\geq 98 \%$ purity. The Zn-Mo/HZSM-5 catalyst was prepared with procedure as reported by Mirzayanti et al. [21-23].

\subsection{Preparation of catalyst}

The H-type ZSM-5 was obtained by simply calcining the as-prepared sample at $550{ }^{\circ} \mathrm{C}$ for $5 \mathrm{~h}$ and named as HZSM-5 as reported by the previous study [21-23]. The sample of HZSM-5 was modified by designed concentration of $\mathrm{Zn}\left(\mathrm{NO}_{3}\right)_{2} .6 \mathrm{H}_{2} \mathrm{O}$ and $\left(\mathrm{NH}_{4}\right)_{6} \mathrm{Mo}_{7} \mathrm{O}_{24} .4 \mathrm{H}_{2} \mathrm{O}$ aqueous solution with incipient wetness impregnation method [24]. Measurements of Zinc and Mo metals to HZSM-5 were as follows: HZSM-5 was weighed $4.75 \mathrm{~g}$ then dried in oven for $12 \mathrm{~h}$ at $120{ }^{\circ} \mathrm{C}$. Zinc nitrate precursor solution was prepared and then added slowly into the HZSM -5 while stirring using a magnetic stirrer at 30 ${ }^{\circ} \mathrm{C}$ for $3 \mathrm{~h}$. The sample was kept so wet that the precursor solution was completely mixed. The catalyst sample was dried in the oven for $12 \mathrm{~h}$ at $120{ }^{\circ} \mathrm{C}$. The sample is named as $\mathrm{ZincHz}$. Thus, Mo was loaded on the ZincHz catalyst by impregnation while stirring using a magnetic stirrer at $30{ }^{\circ} \mathrm{C}$ for $3 \mathrm{~h}$. The sample was kept and dried at $120{ }^{\circ} \mathrm{C}$ for $12 \mathrm{~h}$. The catalyst was calcined for 5 hours with air flowed at $400{ }^{\circ} \mathrm{C}$. Therefore, the process of reduction was conducted for 3 hours with the flow of $\mathrm{H}_{2}$ gas at a temperature of $450{ }^{\circ} \mathrm{C}$, as reported in previous study [21-23].

\subsection{Catalyst characterization}


The characterization of catalysts used XRD, BET, and EDX for the Zn-Mo/HZSM-5 catalysts as reported in previous studies [23]. Furthermore, the Zn-Mo/HZSM-5 catalysts has been presented in previous studies [21]. By energy dispersive X-ray, the metals content was 3.25 wt.\% of Zinc and 6.34 wt.\% of Mo of the total catalyst weight. The sample of the catalyst was denoted as Zn-Mo/HZSM-5_101 catalyst as reported in previous study [23]. Other prepared catalysts with different metal ratios obtained metal content was 2.86 wt.\% of Zinc and 5.32 wt.\% of Mo of the total catalyst weight from EDX analyzed. The catalyst was named as Zn-Mo/HZSM-5-_102.

\subsection{Catalytic hydrocracking experiments}

Figure 3 shows the equipment used to make biofuel from Ceiba pentandra oil by catalytic hydrocracking process using Zn-Mo/HZSM-5 catalyst. The catalytic hydrocracking process was performed using a slurry pressure batch reactor type PARR 4563 with a maximum volume of $600 \mathrm{~mL}$. The reactor was equipped with heating elements. Ceiba pentandra oil as much as $200 \mathrm{~mL}$ and Zn-Mo/HZSM-5 catalyst as much as $1 \mathrm{~g}$. After the oil and catalyst were prepared in the reactor, the $\mathrm{N}_{2}$ gas was then flowed into the reactor for 5 minutes to remove oxygen. Then the flow of $\mathrm{N}_{2}$ was stopped and replaced with $\mathrm{H}_{2}$ gas for 1 hour to assist the catalytic hydrocracking reaction process to reach \pm 10 -15 bar pressure. The reactor was heated to an operating temperature according to the desired variable and maintained for $2 \mathrm{~h}$. After the catalytic hydrocracking reaction process was over, the reactor was cooled to $30{ }^{\circ} \mathrm{C}$. The reaction temperature was varied to be 300 , $325,350,375$, and $400^{\circ} \mathrm{C}$.

\subsection{Product analysis}

The liquid hydrocarbon products were analyzed by gas chromatography-mass spectrometry with standard GC: Agilent HP 6890 models 19091S-433, HP-5 MS capillary column $30 \mathrm{~m} \mathrm{x}$ $250 \mu \mathrm{m} \times 0.25 \mu \mathrm{m}$. It was held at nominal initial pressure $13.31 \mathrm{psi}$, initial flow $1.0 \mathrm{~mL} / \mathrm{min}$ and average velocity $38 \mathrm{~cm} / \mathrm{sec}$. The temperature for the oven was at $150{ }^{\circ} \mathrm{C}$ for $2 \mathrm{~min}$, then it increased to $240{ }^{\circ} \mathrm{C}$ at a rate of $10^{\circ} \mathrm{C} / \mathrm{min}$ for $13 \mathrm{~min}$. The calculations of biofuel compound was grouped into gasoline, kerosene, and gasoil were based on GC-MS as reported in previous studies [21-23]. The hydrocarbon components with a probability match equal to or higher than $80 \%$ were considered. Hydrocarbons (i.e. paraffin, aromatic, cyloparaffin, and olefin) contained in biofuel were defined as gasolinelike hydrocarbon $\left(\mathrm{C}_{5}-\mathrm{C}_{9}\right)$, kerosene-like hydrocarbon $\left(\mathrm{C}_{10}-\mathrm{C}_{13}\right)$, and gasoil-like hydrocarbon $\left(\mathrm{C}_{14}-\mathrm{C}_{22}\right)$, as reported by Barron et al. [25].

The liquid hydrocarbon product of Ceiba

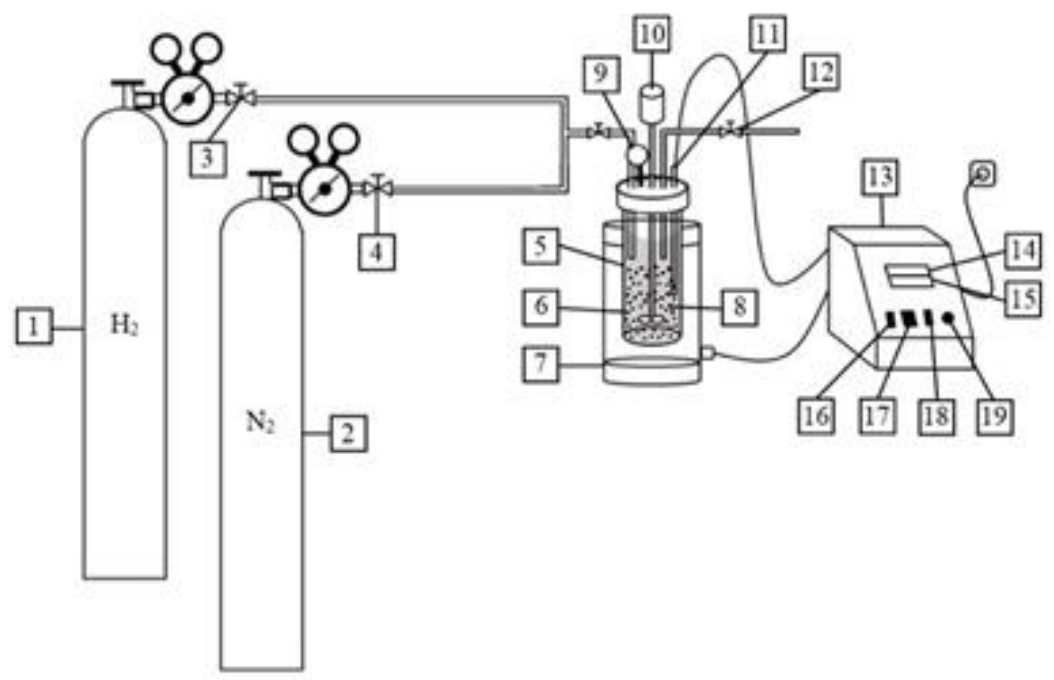

Figure 3. Catalytic hydrocracking process equipment, consisting of: 1) Gas tube $\mathrm{H}_{2}, 2$ ) $\mathrm{Gas}_{\text {tube }} \mathrm{N}_{2}$, 3) Tube valve gas $\mathrm{H}_{2}$, 4) Tube valve gas $\mathrm{N}_{2}$, 5) Reactor, 6) Cotton seed oil (Ceiba pentandra), 7) Heater, 8) Catalyst, 9) Reactor pressure indicator, 10) Stirrer, 11) Thermocouple, 12) Control panel pressure batch reactor, 13) Pressure release control, 14) Display temperature of reactor, 15) Display set point temperature, 16) Power control panel heater and stirrer, 17) Power heater button, 18) Stirrer power button and 19) Stirrer speed control keys 
pentandra oil were performed by GC-MS and Fourier Transformed Infra Red (FTIR) spectroscopy analyses. Definition of biofuel conversion and selectivity were shown in Equation (1) and (2):

Conversion $(\%)=\frac{X_{A}-X_{P}}{X_{A}} \times 100$

Selectivity $(\%)=\frac{P_{P}}{P_{H C}} \times 100$

where $X_{A}$ is the \% area of carboxyl acid feed, $X p$ is \% area of carboxyl product, $P p$ is the n-paraffin in product, and $P_{H C}$ is \%area total hydrocarbon.

\section{Results and Discussion}

\subsection{Composition of Ceiba pentandra oil}

The triglyceride fatty acid composition of Ceiba pentandra oil are given in Table 1, which shows the triglyceride fatty acid profile of linoleic acid (75.85\%), palmitic acid (21.12\%), and pelargonic acid $(0.03 \%)$. The same result was reported by Kathirvelu et al. [26], i.e. stated that the largest fatty acid composition in Ceiba pentandra seed oil is linoleic acid of $37.45 \%$. The high content of unsaturated fatty acid makes it a stable liquid at room temperature [26]. The dominant composition of Ceiba pentandra oil including a group of unsaturated fatty acids (poly-unsaturated fatty acids, PUFA). Polyunsaturated fatty acids are fatty acids composed of molecules of carbon atoms having more than one double bond. The double bond causes these fatty acid molecules to become unsaturated with hydrogen atoms [27]. Physicochemical analysis was performed on Ceiba pen- tandra oil to analyze the quality of feedstock. The results are showed in Table 2. The acid value is an important parameter to indicate the quality, age and purity degree of an oil [11]. High acid numbers indicate that the free fatty acid content in the oil is high, causing the oil to easily undergo acidification and discoloration. The results of the present study revealed that the acid value of Ceiba pentandra oil was $89.49 \mathrm{mg} \mathrm{KOH} / \mathrm{g}$. The density (at $20^{\circ} \mathrm{C}$ ), kinematic viscosity (at $40{ }^{\circ} \mathrm{C}$ ), and flash point of Ceiba pentandra oil were $0.891 \mathrm{~g} / \mathrm{cm}^{3}, 37.47$ Cst and $308^{\circ} \mathrm{C}$, respectively.

\subsection{Catalyst characterization}

Figure 4 (a) shows $\mathrm{N}_{2}$ adsorption and desorption isotherm as type $\mathrm{I}$, as reported by the previous study [28,29]. The HZSM-5 shows a typical isotherm for microporous materials. After impregnation with Zinc and Mo as shown in Figure 4 (b), the zeolite exhibits a typical irreversible type IV adsorption and desorption isothermal. This characteristic indicates microporous molecular sieves. The pore size distribution indicates that two type pores in the zeolite centered at $3 \mathrm{~nm}$ and $10 \mathrm{~nm}$ were calculated by the BJH method. It can be seen that the curves of adsorption and desorption are approximately parallel from $P / P_{0}=0.5$ to $P / P_{0}=$ 0.9 .

\subsection{Catalytic hydrocracking performance}

The FT-IR spectra of Ceiba pentandra oil may be compared to that of biofuel obtained at $400{ }^{\circ} \mathrm{C}$ for $2 \mathrm{~h}$ using Zn-Mo/HZSM-5-_102 catalyst to evaluate catalytic hydrocracking reaction such as deoxygenation and decarboxyla-

Table 1. The composition of fatty acid triglyceride of Ceiba pentandra oil

\begin{tabular}{lccc}
\hline Fatty acid triglyceride & Systematic Name & Formula & \% Qualitative \\
\hline Pelargonic acid & Nonanoic acid & $\mathrm{C}_{9} \mathrm{H}_{18} \mathrm{O}_{2}$ & 0.03 \\
Palmitic acid; C16:0 & n-Hexadecanoic acid & $\mathrm{C}_{15} \mathrm{H}_{31} \mathrm{COOH}$ & 21.12 \\
Linoleic acid; C18:2 & 9,12-Octadecadienoic acid & $\mathrm{C}_{17} \mathrm{H}_{31} \mathrm{COOH}$ & 78.85 \\
\hline
\end{tabular}

Table 2. Phycochemical properties of Ceiba pentandra oil used in the work

\begin{tabular}{lcc}
\hline Properties & Value & Method \\
\hline Density $\left(\mathrm{g} / \mathrm{cm}^{3}\right)$ & 0.891 & - \\
Kinematic viscosity at $\left(40^{\circ} \mathrm{C}, \mathrm{Cst}\right)$ & 37.47 & ASTM D445-97 \\
High Heating Value $(\mathrm{Btu} / \mathrm{lb})$ & 19168 & ASTM D240 \\
Acidic Index $(\mathrm{mg} \mathrm{KOH} / \mathrm{g})$ & 89.49 & SNI 7431:2008 \\
Iodine value $\left(\mathrm{g} . \mathrm{I}_{2} / 100 \mathrm{~g}\right)$ & 52.15 & SNI 7381:2008 \\
Flash Point, ${ }^{\circ} \mathrm{C}$ & 308 & ASTM D93 \\
\hline
\end{tabular}


tion through the disappearance of the absorption peaks corresponding to functional groups of oxygenated compounds as shown in Figure 5. Figure 5a shows FTIR spectra Ceiba pentandra oil. The bonding type of some functional groups in Ceiba pentandra oil shows the presence of the bonds of the carboxylic acid group in the absorption area of $3008.06 \mathrm{~cm}^{-1}$, the saturated or unsaturated alkanes in the absorption area $2921.79 \mathrm{~cm}^{-1}$ and $2852.56 \mathrm{~cm}^{-1}$ and the ester in the absorption area $1724.87 \mathrm{~cm}^{-1}$ and 1159.35 $\mathrm{cm}^{-1}$. This result is in accordance with the re-
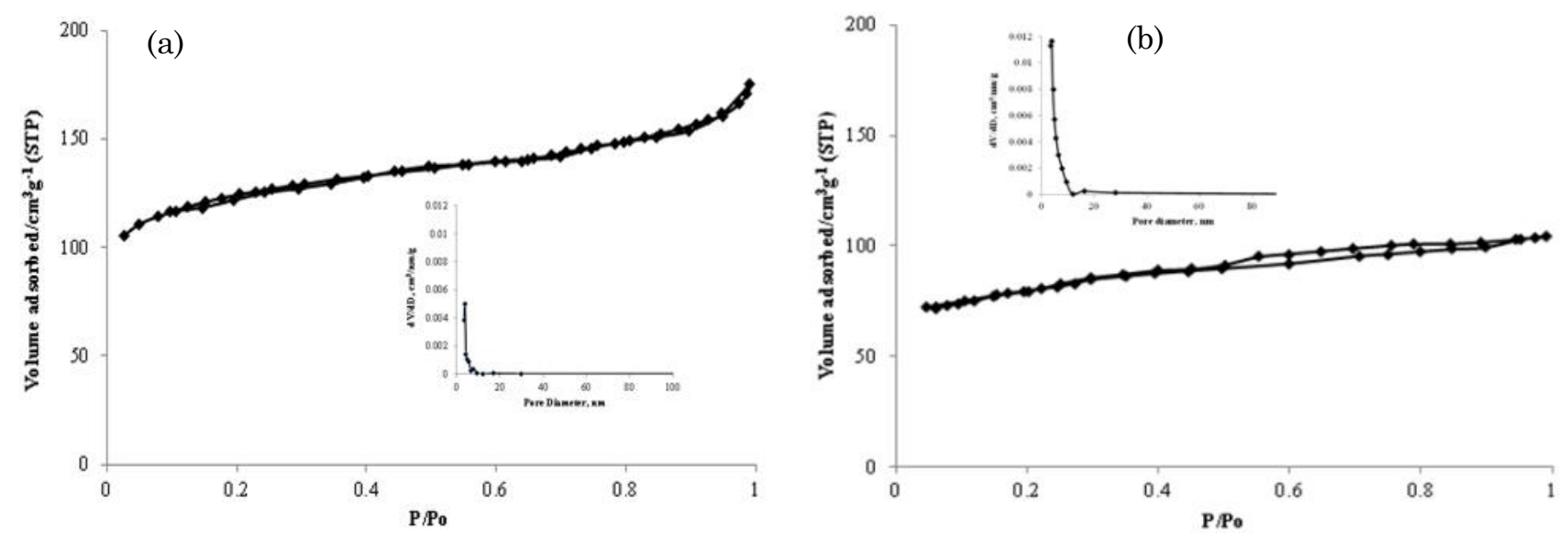

Figure 4. $\mathrm{N}_{2}$ adsorption and desorption isotherm and pore distribution of (a) HZSM-5, (b) ZnMo/HZSM-5_102 catalyst
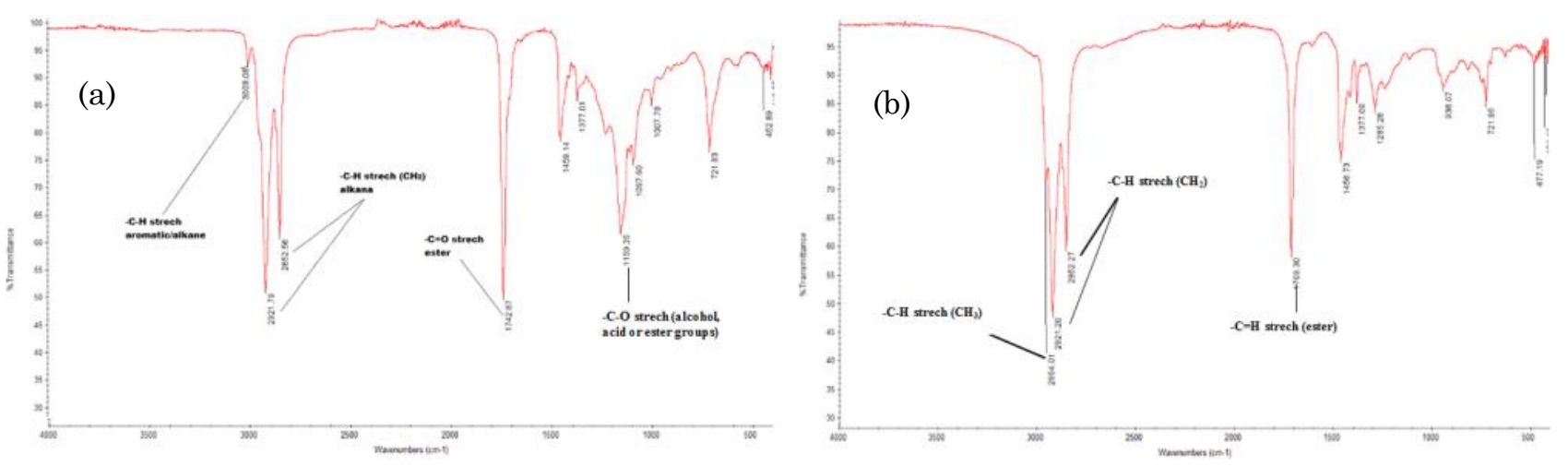

Figure 5. FTIR spectra of (a) Ceiba pentandra oil, (b) liquid hydrocarbon product obtained at $400{ }^{\circ} \mathrm{C}$ for 2 h using Zn-Mo/HZSM-5_102 catalyst
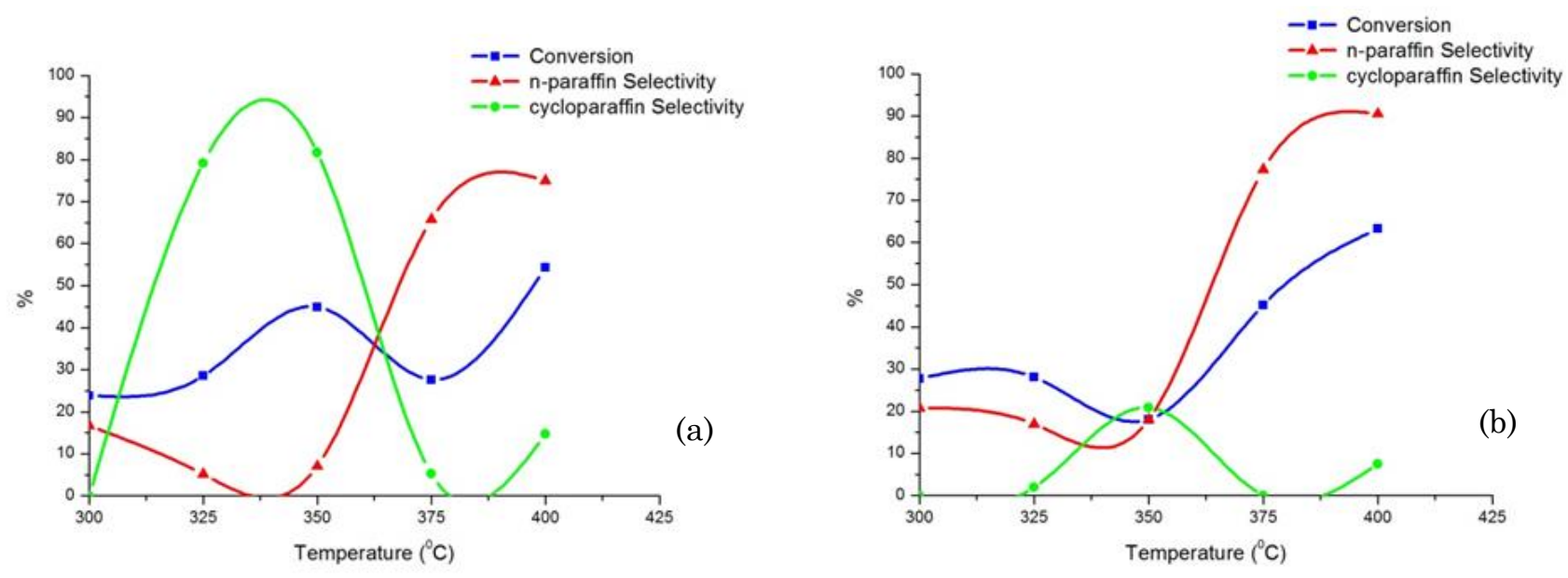

Figure 6. The effect of reaction temperature on conversion and selectivity of liquid hydrocarbon products using Zn-Mo/HZSM-5_102 catalyst type 
sults of GC-MS analysis that has been done in the previous study [22].

Figure 5b shows the FTIR spectra of liquid hydrocarbon product at $400{ }^{\circ} \mathrm{C}$ with $\mathrm{Zn}$ Mo/HZSM-5_102 catalyst. The spectra showed that the functional group of the carbonyl ester group $1724.87 \mathrm{~cm}^{-1}$ and the acid or ester group $1159.35 \mathrm{~cm}^{-1}$ were undetectable in liquid hydrocarbon product. This shows that oxygen removal has occurred through the process of catalytic cracking and hydrogenation of ester bonds. The adsorbed hydrocarbons are clearly visible on the region between 2954.01, 2921.20, and $2852.27 \mathrm{~cm}^{-1}$ for alkyl groups of $\mathrm{C}-\mathrm{H}$ bonds. This proves that the presence of $\mathrm{ZnO}$ and $\mathrm{MoO}_{2}$ metals are distributed in HZSM-5, as has been previously reported [21], proved capable of hydrogenated the linoleic acid triglycerides Ceiba pentandra oil into hydrocarbon compounds. In addition, the catalytic hydrocracking process is affected by the presence of HZSM- 5 as support.

Figure $6 \mathrm{a}$ shows the effect of the $\mathrm{Zn}$ Mo/HZSM-5_101 catalyst type on the conversion and selectivity of the resulting liquid hydrocarbon product. The highest conversion of $54.35 \%$ was achieved at $400{ }^{\circ} \mathrm{C}$. At $300{ }^{\circ} \mathrm{C}$, the paraffin selectivity reached $16 \%$ and then decreased and increased sharply from 350 to 400 ${ }^{\circ} \mathrm{C}$. According to the performance of the $\mathrm{Zn}$ Mo/HZSM-5_101 catalyst in the catalytic hydrocracking process on the cotton seed oil, the selectivities of n-paraffin and cycloparaffin were $75.00 \%$ and $14.73 \%$ at temperature of $400{ }^{\circ} \mathrm{C}$, respectively. Figure $6 \mathrm{~b}$ shows the effect of Zn-Mo/HZSM-5_102 catalyst type on the conversion and selectivity of the resulting liquid hydrocarbon product. The highest conversion of $63.31 \%$ was achieved at temperature of $400{ }^{\circ} \mathrm{C}$. At temperature of $300{ }^{\circ} \mathrm{C}$, the paraffin selectivity reached $20.75 \%$ and then decreased and increased sharply from 375 to $400{ }^{\circ} \mathrm{C}$. According to the performance of the Zn-Mo/HZSM-5_102 catalyst in the catalytic hydrocracking process on the cotton seed oil, the n-paraffin, and cycloparaffin selectivities were $90.52 \%$ and $7.44 \%$ $\%$ at temperature of $400{ }^{\circ} \mathrm{C}$, respectively.

\section{Conclusions}

Bifunctional catalytic hydrocracking catalysts, Zn-Mo/HZSM-5, were prepared by incipient wetness impregnation method. The production of Ceiba pentandra gasoil range hydrocarbon was used Zn-Mo/HZSM-5 successfully to produce high conversion and selectivity in various reaction temperature. The maximum conversion performance is given by $\mathrm{Zn}-\mathrm{Mo} / \mathrm{HZSM}$ 5-_102 catalyst to produce gasoil range hydro- carbons through catalytic hydrocracking of $\mathrm{Cei}$ ba pentandra oil of $63.31 \%$. The $n$-paraffin selectivity was $90.52 \%$, while that of cycloparaffin was $7.44 \%$ at $400{ }^{\circ} \mathrm{C}$.

\section{Acknowledgments}

Thanks for the crews of laboratory, namely Varantika Eka Pramesti and Muhammad Faishal Razin, Department of Chemical Engineering, Sepuluh Nopember Institute of Technology.

\section{References}

[1] Asri, N.P., Machmudah, S., Wahyudiono, W., Suprapto, S., Budikarjono, K., Roesyadi, A., Goto, M. (2013). Palm Oil Transesterification in Sub and Supercritical Methanol with Heterogeneous Base Catalyst. Chemical Engineering and Processing Process Intensification, 72: 63-67.

[2] Kouzu M., Hidaka, J.S. (2012). Transesterification of Vegetable Oil into Biodiesel Catalyzed by CaO: A Review. Fuel, 93: 1-12.

[3] Fei, L., Reddy, K.H., Hill, J., Lin, Q., Yuan, B., Xu, Y., Dailey, P., Deng, S., Luo, H. (2012). Preparation of Mesoporous SilicaSupported Palladium Catalysts for Biofuel Upgrade. Journal of Nanotechnology. Vol. 2012 . Article ID: 309093 . (doi:10.1155/2012/309093).

[4] Taufiqurrahmi, N., Bhatia S. (2011). Catalytic Cracking of Edible and Non-Edible Oils for the Production of Biofuels. Energy Environ. Sci., 4: 1087-1112.

[5] Romero, M., Pizzi, A., Toscano, G., Casazza, A.A., Busca, G., Bosio, B., Arato, E. (2015). Preliminary Experimental Study on Biofuel Production by Deoxygenation of Jatropha Oil. Fuel Processing Technology, 137: 31-37.

[6] Marlinda, L., Al-Muttaqi, M., Gunardi, I., Roesyadi. A., Prajitno, D.H. (2017). Hydrocracking of Cerbera manghas Oil with CoNi/HZSM-5 as Double Promoted Catalyst. Bulletin of Chemical Reaction Engineering \& Catalysis, 12: 167-184.

[7] Al-Muttaqii, M., Marlinda, L., Roesyadi, A., Prajitno, D.H. (2017). Co-Ni/HZSM-5 Catalyst for Hydrocracking of Sunan Candlenut Oil (Reutealis Trisperma (Balnco) Airy Shaw) for Production of Biofuel. J. Pure App. Chem. Res., 6(2): 84-92.

[8] Prajitno, D.H., Budianto. A., Iqbal. M., Purnomo. V. (2014). Modification of NiZn/HZSM-5 Double Promote Catalyst for Biofuel Production from Cerbera manghas Oil. The $9^{\text {th }}$ Joint Conference on Chemistry, 12-13 
November 2014, Semarang.

[9] Roesyadi, E. (2012). Konversi Minyak Nabati Menjadi Green Diesel dan Green Gasoline dengan Proses Hydrocracking dan Hydrotreating pada Katalis $\mathrm{NiMo} / \mathrm{Al}_{2} \mathrm{O}_{3}$, Ni$\mathrm{Mo} / \mathrm{Al}_{2} \mathrm{O}_{3}-\mathrm{SiO}_{2}, \mathrm{NiMo} / \mathrm{SiO}_{2}$, dan NiMo/Zeolit. PhD Dissertation, Institut Teknologi Sepuluh Nopember, Surabaya.

[10] Liu, C., Liu, J., Zhou, G., Tian, W., Rong, L. (2013). A Cleaner Process for Hydrocracking of Jatropha Oil into Green Diesel. Journal of the Taiwan Institute of Chemical Engineers. 44: $221-227$

[11] Bokhari, A., Chuah, F.L., Yusup, S., Ahmad, J., Shamsuddin, R.M., dan Teng, K.M. (2015). Microwave-assisted Methyl Esters Synthesis of Kapok (Ceiba pentandra) Seed Oil: Parametric and Optimization Study. Biofuel Research Journal, 7: 281-287.

[12] Cooper, B. (1963). A Postulated Role of Fatty Acids in Petroleum Formation. Geochimica et Cosmochimica

[13] Mohammad, M., Hari, T.K., Yaakob, Z., Sharma, Y.C., Sopian, K. (2013). Overview on the Production of Paraffin Based-Biofuels via Catalytic Hydrodeoxygenation. Renewable and Sustainable Energy Reviews, 22: 121-132.

[14] Veriansyah, B., Han, J.Y., Kim, S.K., Hong, S., Kim, Y.J., Lim, J.S., Shu, Y-W., Oh, S-G., Kim, J. (2012). Production of Renewable Diesel by Hydroprocessing of Soybean Oil: Effect of Catalyst. Fuel, 94: 578-585.

[15] Kubicka, D., Kaluza, L. (2010). Deoxygenation of Vegetable Oils over Sulfuded Ni, Mo, and NiMo Catalyst. Applied Catalyst A: General, 372: 199-208.

[16] Krar, M., Kasza, T., Cs Toth., Hancsok, J. (2008). Inverstigation of the Heterogeneous Catalytic Transformation of Vegetable Oil/Gas Oil Blends. Hungarian Journal of Industrial Chemistry. 36: 71-76.

[17] Zhao, X., Wei, L., Cheng, S., Kadis, E., Cao, Y., Boakye, E. (2016). Hydroprocessing of Carinata Oil for Hydrocarbon Biofuel over Mo- $\mathrm{Zn} / \mathrm{Al}_{2} \mathrm{O}_{3}$. Applied Catalysis B: Environmental. 196: 41-49.

[18] Sandstede, G., Lehmann, T. (2014). Catalyst with Supplement Component for Hydroprocessing of Bio-Feedstock. Pub. No. US 20140058182 A1. Pub date: Feb 27, 2014.

[19] Gates, B.C. (1992). Catalytic Chemistry. Page 277, 292, 295. John Wiley and Sons Inc.

[20] Sousa, L.A., Zotin, J.L., da Silva, T. (2012). Hydrotreatment of Sunflower Oil Using Supported Molybdenum Carbide. Applied Catalysis A: General. 449: 105-111.
[21] Mirzayanti, Y.W., Prajitno, D.H., Roesyadi, A. (2017). Catalytic Hydrocracking of Kapuk Seed Oil (Ceiba pentandra) to Produce Biofuel Using Zn-Mo Supported HZSM-5 Catalyst. $7^{\text {th }}$ International Conference on Environment and Industrial Innovation, IOP Publishing.

[22] Mirzayanti, Y.W., Roesyadi. A., Prajitno, D.H. (2017). Catalytic Hydrocracking to Biofuel of Kapuk Seed Oil (Ceiba pentandra) using Zn-Mo/HZSM-5 Catalyst. The $7^{\text {th }}$ Annual Basic Science International Conference, Brawijaya University, March 7th_-8th 2017.

[23] Mirzayanti, Y.W., Kurniawansyah, F., Prajitno, D.H., Roesyadi, A. (2017). Conversion of Kapuk Seed Oil via Catalytic Hydrocracking for Hydrocarbon Biofuel Using ZincMolybdenum Supported Zeolite Catalyst: Effect of Reaction Temperature. Basic and Applied Sciences Interdisciplinary Conference 2017 (BASIC 2017), Indonesia University, Agustus 18th-19th 2017.

[24] Chen, L., Li, H., Fu, J., Miao, C., Lv, P. (2015). Catalytic Hydroprocessing of Fatty Acid Methyl Esters to Renewable Alkane Fuels over Ni/HZSM-5 Catalyst. Catalysis Today. 259: 266-276.

[25] Barrón, C.A.E., Melo-Bandaa, J.A., Dominguez, E.J.M., Hernández, M.E., Silva, R.R., Reyes, T.A.I., Meraz, M.M.A. (2011). Catalytic Hydrocracking of Vegetable Oil for Agrofuels Production Using Ni-Mo, Ni-W, Pt and TFA Catalysts Supported on SBA-15. Catalysis Today. 166: 102-110.

[26] Kathirvelu, S., Moorthi, N.S.V., Krishnan, S.N., Mayilsamy, K., Krishnaswamy, T. (2014). Production of Biodiesel from Non Edible Ceiba Pentandra Seed Oil Having High FFA Content. ARPN Journal of Engineering and Applied Sciences. 9(12): 2625-2634.

[27] Solomon, T.W.G., Fryhle, C.B. (2011). Organic Chemistry. 10 $0^{\text {th }}$ ed. John Wiley dan Sons Inc Wiley USA

[28] Ni, Y., Sun, A., Wu, X., Hai, G., Hu, J., Li, T., Li, G. (2011). Preparation of Hierarchical Mesoporous Zn/HZSM-5 Catalyst and its Application in MTG Reaction. Journal of Natural Gas Chemistry. 20: 237-242.

[29] Hao, K., Shen, B., Wang, Y., Ren, J. (2012). Influence of Combined Alkaline Treatment and Fe-Ti-loading Modification on ZSM-5 Zeolite and its Catalytic Performance in Light Olefin Production. Journal of Industrial and Engineering Chemistry. 18: 1736-1740. 